\title{
Changing Urban Pattern of Eminönü: Reproduction of Urban Space via Current Images and Function
}

\author{
By Tuba Sari*
}

\begin{abstract}
Considering the mixture of civilizations as one of the central locations of Istanbul, the Eminonü district has many different urban patterns related to its historical background. The Eminonü representing local Istanbul has always been a center for trade and production of traditional handcrafts throughout the history. However, the radical changes Istanbul encountered between the 19th and 20th century caused a transformation of its local context. By the 19th century, accepted as a period of modernization of Istanbul, the main commercial areas of Eminönü were transformed into modern office blocks, although conventional facades still fronted old-style courtyards. After planning arrangements in the republican era, Henry Prost's plan directed changes to the urban pattern, aiming to create a new public square in Eminönü by the demolishing parasite buildings on the northern side of Yeni Valide Mosque. Considering the rapid urbanization period of the 20th century, Eminonü preserved its urban pattern despite its changing contents until today. So, it has become one of the rarest areas in Istanbul that still resists through time despite its daily-use. Therefore, focusing on the busiest areas of Eminonü, this paper aims to reveal the changing structure of its continuous urban fabric by daily participation of users. The case study consists of Eminönü Square and its connected areas such as the harbor, commercial areas, passing areas and other functional spaces. During the research process, the old maps of Istanbul-Eminonü have been examined, besides the observation of the current image of the place. The main purpose of the research is to remark on the relationships and contradictions between the historical urban pattern and the current image of the city. In this respect, Eminönü has been evaluated with its changing urban fabric due to new user experiences and current images of the place.
\end{abstract}

\section{Introduction}

The district of Eminönü is known for its traditional commercial spaces and trade functions rather than residential areas in the Historical Peninsula of Istanbul. This research deals with the major alterations that occurred on the Eminönü Square as part of the urbanization process of Istanbul between the $19^{\text {th }}$ century and the beginning of the $21^{\text {st }}$ century. The urban interventions that affected the form and the structure of the Square coincide with the urban planning process. At the end of the $19^{\text {th }}$ century, the development of transportation infrastructure such as the construction of the Galata Bridges, maritime transportation, the Sirkeci railway station and trams increased traffic density between the two sides of the Galata Bridge. With the new transportation

\footnotetext{
${ }^{*}$ Research Assistant, Istanbul Technical University, Turkey.
} 
system, an increase of new commercial facilities altered the image of the Eminönü district. The study aims to reveal the changing structure of Eminönü considering new functions of the urban area. The case study consists of Eminönü Square and its connected areas such as the harbor, commercial areas, passing areas and other functions.

The first part of the study focuses on the monumental structures surrounding Eminönü Square, including Yeni Valide Mosque, Egypt Bazaar, city walls and the gates. The second part of the study deals with the changing image of the Eminönü area. After mentioning the historical background of the space, the urban interventions leading to the transformation of the Eminönü are examined through urban planning decisions and reconstruction processes in different periods. Since the $19^{\text {th }}$ century, urban reforms presenting the modernization of the Ottoman state, such as the construction of Galata Bridge connecting the two sides of the city (Galata and Historical Peninsula), have been the significant thresholds in the transformation of the area. In addition to that, Henri Prost, the urban planner who came to Turkey by invitation of Atatürk in 1936 to create the Master Plan of Istanbul, realized several renovations for Istanbul defining the main road network of the city and reshaping Eminönü Square with the demolition of buildings, which caused a noticeable change in the urban area in the $20^{\text {th }}$ century.

Considering the recent transformation of Eminönü district in the $20^{\text {th }}$ century, Menderes (1950-1960) and Dalan (1980-1990) operations represent the major urban interventions leading to changes in the area, as a continuation of Henri Prost's planning studies in the 1940s. By the opening of the main road of Eminönü-Unkapanı in the Menderes operations, the buildings between Eminönü and Unkapanı were thoroughly demolished and the well-defined boundaries of Eminönü Square started to lose their local characteristics. All these operations affected the current image of Eminönü Square and caused new projects to be developed for the rearrangement of the square in the $21^{\text {st }}$ century.

\section{Literature Review: The Structures Surrounding Eminönü Square}

Eminönü was the center of trade, transportation, storage, administrative and military functions in the Byzantine period. The gates and piers determined the commercial circulation, the urban fabric and the city border at that time. The mosque and its complex 'kulliye', with its additional buildings, constituted a new city structure in the Eminönü district economically, physically and sociologically. The mosque's harim (the main prayer hall) with its three gates in the city walls on the northern side and the ' $L$ ' shaped market on the southern side were gradually demolished in the 1900s. The harim of the mosque was totally covered by buildings and transformed into an open public space. The walls and the gates of the mosque were replaced by new buildings during that time. In the context of modernization reforms of the $19^{\text {th }}$ century, the construction style of buildings changed in terms of technology and style 
reflecting European architecture. New structures such as the bridge of Galata, the new steamers and ferry stations, the Eminönü quay and its outbuildings, and the tramway started to modify the form and functional pattern of the square. The square transformed into a center of urban transportation in the 19th century with different transportation systems.

The Yeni Valide Mosque being a monumental structure in Eminönü district was located next to the harbor on the southern bank of the Golden Horn. This religious structure was built by Safiye Sultan who entrusted Davud Ağa, Architect-in Chief to the Ottoman Sultan, as the head of one of Istanbul's most important quays in the Bahçekapı area in 1597. The Yeni Valide Mosque was planned as the structure of külliye, being a large complex composed of the mosque, a sultan's kiosk, a space for the Kur'an readers, the tomb of Turhan Sultan, the Kur'an school, public fountains, stores and a closed, L-shaped spice bazaar known as Egypt Market ${ }^{1}$ (see Figure 1).

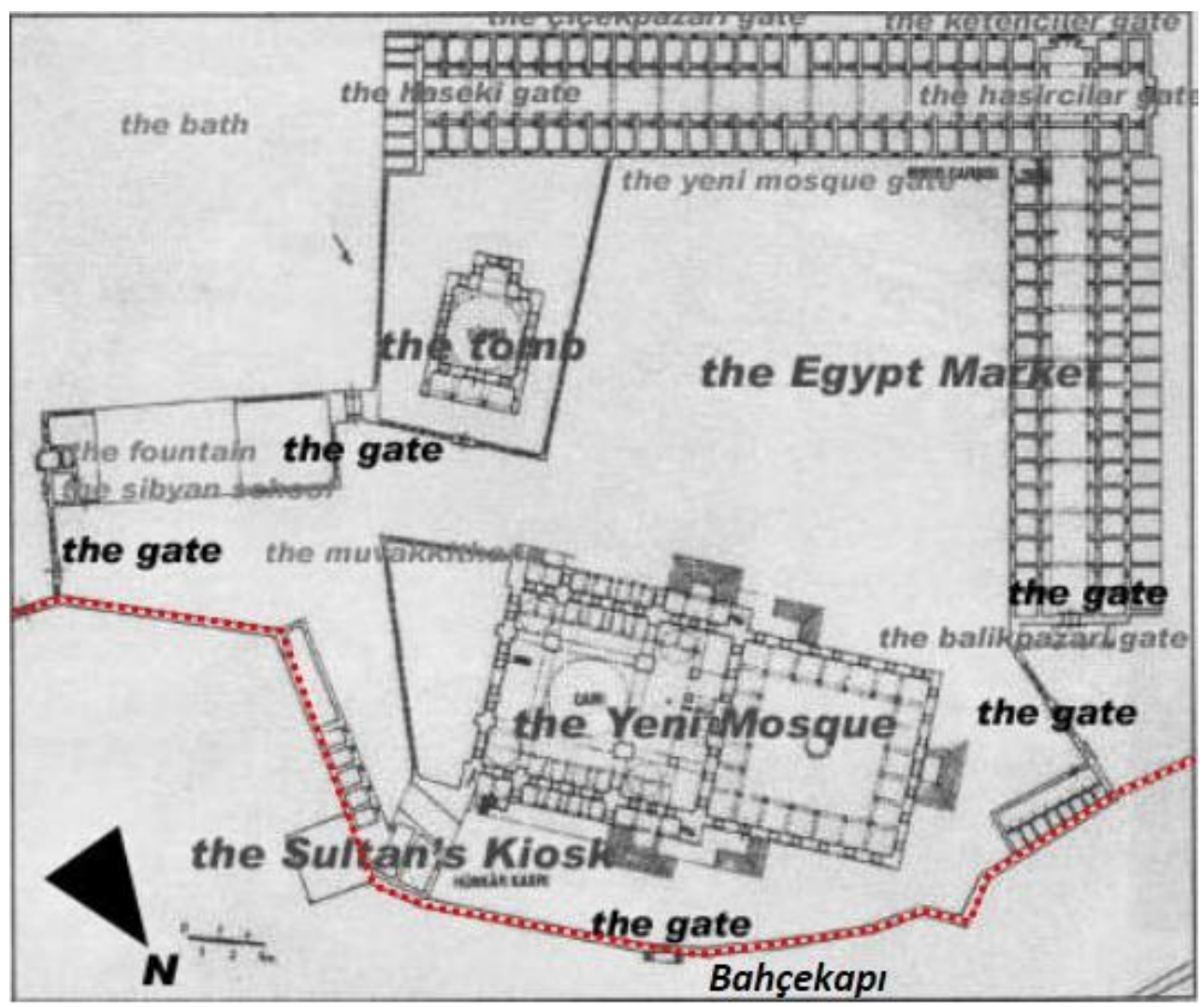

Figure 1. Yeni Valide Mosque, Egypt Market (Plan) with the Gates

There were three gates, which existed before the construction of the mosque, in the old city walls that limited the boundary of the outer courtyard of Yeni Valide Mosque. Bahçekapı on the east side of, Çıfitkapısı on the north side, and Balıkpazarı near the gate of Egypt Market were the main gates as part of both the harim of the mosque and the Byzantine city walls (see Figure 2). The earthquake of 1867 destroyed that of Bahçekap1. There was a passage in the

1. Ali Saim Ulgen, "Yenicami," Vakıflar Dergisi 2 (1974): 75-78. 
place of the gate, which was a communication point between Eminönü Square and the inner city.

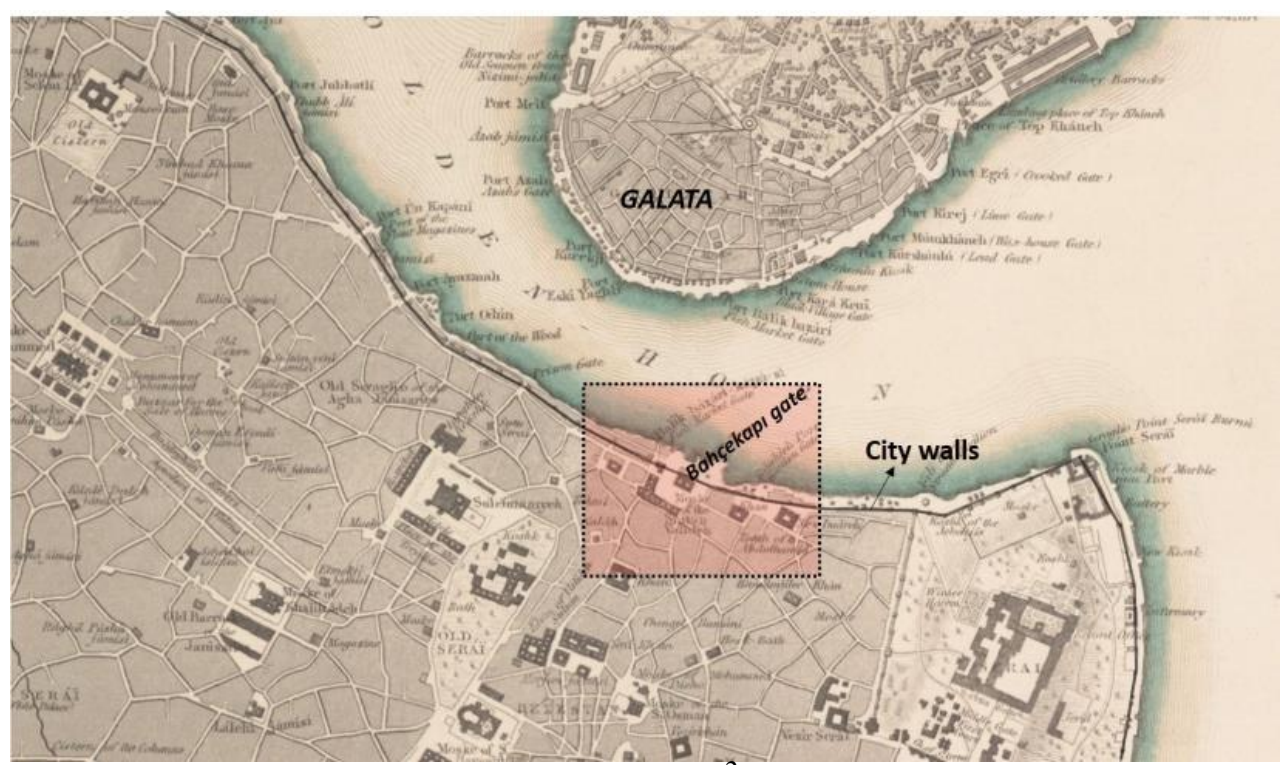

Figure 2. Istanbul's Old City Map in $1853^{2}$

Bahçekapı and the nearby area were a commercial zone surrounded by a dense Jewish neigbourhood and settlements in the past. The Jewish people lived in Eminonï until the construction of the Yeni Valide Mosque. According to the statement of Kuban, ${ }^{3}$ seventeen Jewish localities were recorded in the vakfiye of Conqueror, and the houses of Jewish communities were placed along the shores of the Golden Horn from Sirkeci inwards. By the construction of the Yeni Valide Mosque, the Jewish communities were forced to migrate to Balat and Hasköy in Galata district of Istanbul. The church and synagogue in the area were demolished after the construction of the mosque.

Physical remains of the walls between Bahçekapı and Yeni Cami Gate can be seen in some parts of the district today. With the construction of the Galata Bridge in 1845 and demolition of the outer courtyard walls, a larger square emerged at the waterfront with commercial buildings built along the mosque. The two three-storey buildings enclosed the square and form the foreground. Yeni Valide Mosque was the dominant vertical element on the background in the 1900s (see Figure 3). The buildings on both sides of the Yeni Cami Gate to Balıkpazarı were demolished in the Republican period. A larger street came into existence in the place of Balıkpazar1 Gate. However, the Egypt Bazaar and the waterfront relation was the same until 1930s. ${ }^{4}$

2. IBB, "Istanbul Urban Layers," http://www.istanbulurbandatabase.com/.

3. Dogan Kuban, Istanbul an Urban History (Istanbul: Economic and Social History Foundation of Turkey, 1996).

4. Nuran Erkal, Haliç Extra-Mural Zone: A Spatio-Temporal Framework for Understanding the Architecture of the Istanbul City Frontier (METU, 2001). 


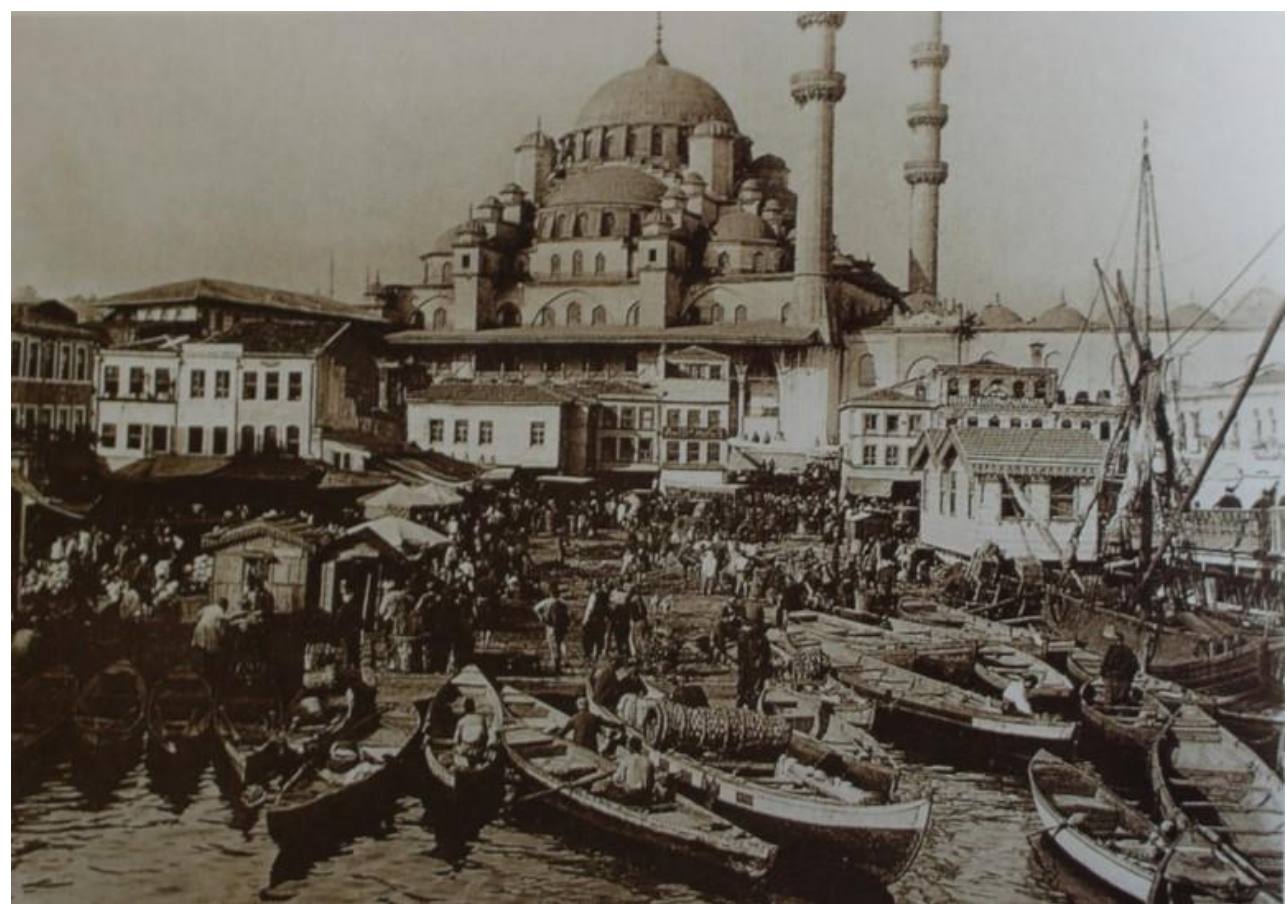

Figure 3. The Commercial Quays in Eminönü, at the Beginning of Golden Horn ${ }^{5}$

\section{Methodology}

In the process of this study, it several visual materials such as old maps and photographs of Eminonü were consulted in addition to an extensive literature review. Eminönü Square and its surroundings are examined through time, discussing the changing image of the place by an observation of process and structures. The main purpose of the research is to remark on the relationships and contradictions between historical urban patterns and current images of the city. In this respect, Eminönü is evaluated with its changing urban fabric due to new user experiences and current images of the place.

\section{Findings/Results: The Changing Image of the Eminönü District}

\section{Historical Background of the Space}

Istanbul has interacted with various cultures and people because of its geographical location and has become an important center of trade and industry in many periods of history. Because the city has been a connection point for traffic between the Black Sea and the Aegean, it has become an important fishing center and trade center since the pre-Hellenistic period of Byzantine era. The harbor square, which coincides with the city's Golden Horn and Eminönü district, has been organized with open commercial centers to support

5. Ekrem Isin, İstanbul'da Gündelik Hayat (Istanbul: İletişim Yayınları, 1995). 
this activity. This central region of Byzantion has emerged as an important area where protection functions are intensified by the walls, which extend along trade, transport and storage. ${ }^{6}$

After the conquest of the city in the 15th century, the harbor activities from Sirkeci to the Golden Horn created the major spaces of intensive trade circulation. In addition to the developing scaffolds for trade purposes, the shipyards, which hold an important place in the identity of the present Haliç, were also established during this period. To meet the consumption needs of the city, various harbor structures emerged in the area, and each of them specialized in a different product. The quays forming the west side of the Eminönü district, its surrounding area (Yemişpazarı, Unkapanı, Yağkapanı, Odunpazarı quays) and Balat became prominent as places where consumption items were evacuated, and port activities, commercial activities and storagedistribution work were carried out. ${ }^{7}$

The Eminönü district, where the shores of the Golden Horn, the Galata and Historical Peninsula regions intersected, constituted the most vivid part of the city in terms of economy, maritime transport and commerce, customs, inns, warehouses and workplaces. This large port city of Istanbul has undertaken the function of an intensive business center, where imported goods are emptied and stored, as well as the services of thousands of sailors and merchants who serve them. As a result, a dense area of khans and bazaars has appeared in the back region of the Eminönü district. While the biggest khans are located on the road leading to the Grand Bazaar, the areas where the khans are concentrated between Unkapanı and the Egypt Bazaar are also noteworthy. Eminönü and its neighborhoods have gained a commercial identity over time as a central place where harbor activities concentrate, which reflects the spatial organization in the area (Figure 4). The $19^{\text {th }}$ century can be considered a period informing the change of the city center and Eminönü. Since the modernization movement of the 19th century, the city center along the shore has taken a form extending towards Galata with the passing activity of Galata Bridge. In this period, the economic and social life of Istanbul was directed to the Galata district with a bridge channel from the line among Eminönü, Sirkeci, Unkapanı and Beyazit.

6. Ilber Ortayli, İstanbul'dan Sayfalar (Istanbul: İletişim Yayınları, 2000).

7. Dilek Erden, "Haliç’te Dönüşüm Ve Tarihsel Süreklilik," in Osmanlı Bankası Arşiv ve Araştırma Merkezi, 2009. 


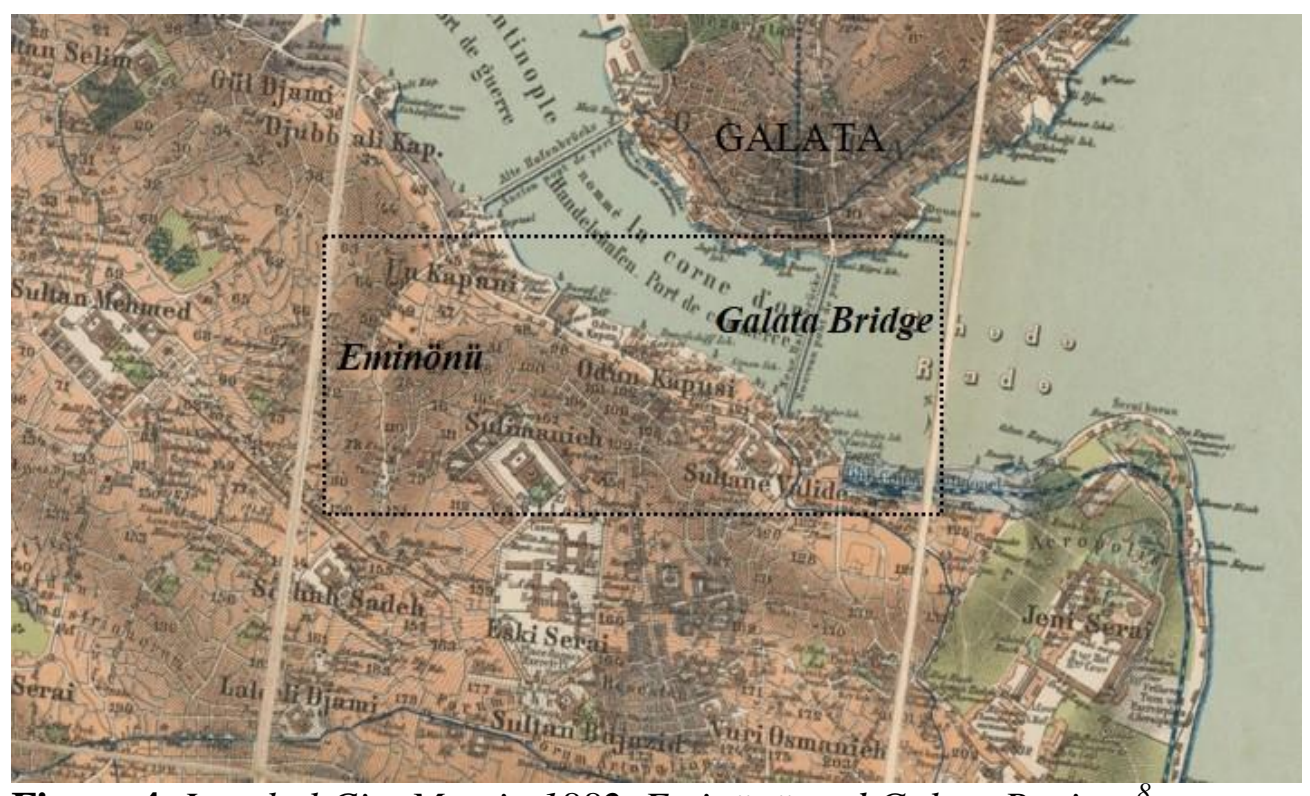

Figure 4. Istanbul City Map in 1882, Eminönü and Galata Regions ${ }^{8}$

\section{The Urban Interventions between the $19^{\text {th }}$ Century and $21^{\text {st }}$ Century}

\section{Urban Reforms: The Tanzimat Edict}

The 19th century was regarded as a period of modernization for Istanbul in urban history literature. The administrative and urban reforms, changing transportation systems, and large-scale urban projects are the most important developments in order to understand the re-shaping of Istanbul. These alterations of restructuring were examined in terms of the effects on Eminonu Square and its surroundings. The structure of the Ottoman State started to modernize after the Tanzimat Edict regarding its planning and administrative reforms, which re-shaped the morphology of Istanbul. The leading effect of the Tanzimat Edict was observed in the regulations of the city fabric with new urban planning reforms. According to Celik ${ }^{9}$ the planning reforms could be described as three "imported customs" from the European system. The first of them was based on the rules and regulations concerning urban planning problems. The second was based on new urban design criteria, which aimed to create road networks, monumental squares, regular facades and monotonous urban fabric according to the new rules and regulations. Thirdly, new building types were shown as the symbols of transformation in the architecture. In conclusion, Celik stated, "the aim of the legislations ordered in the 19th century was to create a city with orthogonal streets and masonry buildings". In Eminönü Square and its surroundings, the outcomes of the legislations caused a change in the

8. IBB, "Istanbul Urban Layers."

9. Zeynep Celik, "19.Yüzyılda Osmanlı Başkenti: Değişen Istanbul19.Yüzyılda Osmanlı Başkenti: Değişen Istanbul,” (trans.) Selim Deringil (İstanbul: İş Bankası Kültür Yayınları, 2016). 
construction and style of buildings. The buildings on the northern side of Yeni Valide Mosque particularly reflected the new construction and style of buildings.

The architecture of Istanbul displayed a city image opened to the West. The change in the architectural style of the structures was observed on some public buildings. For example, one of these structures, the Sirkeci Railway Station, consists of three assembled structures and two clock towers that cover the central body of the building on both sides. The building attracts attention with its horseshoe arches, wide circular leaded windows and minaret-like clock towers. Designed by August Jachmund, the Sirkeci Railway Station reflects the style of $19^{\text {th }}$ century architecture. ${ }^{10}$

As one of the examples of $20^{\text {th }}$ century architecture in the area, the structure of the General Post Office is similar to the new, lightened and spacious central post offices of European cities. The stone workmanship at the entrance of the five-storey building, which has a rectangular plan, is striking. Marble in stairs and local tiles in ornaments are used. The building had the most advanced construction technology in the years it was built. The building is symmetrical and has a schematic that looks quite simple at first glance. There is a large central hall in the center. In addition to the monumental staircases at the front of the building, the most striking aspect is the two tower extensions (see Figure 5).
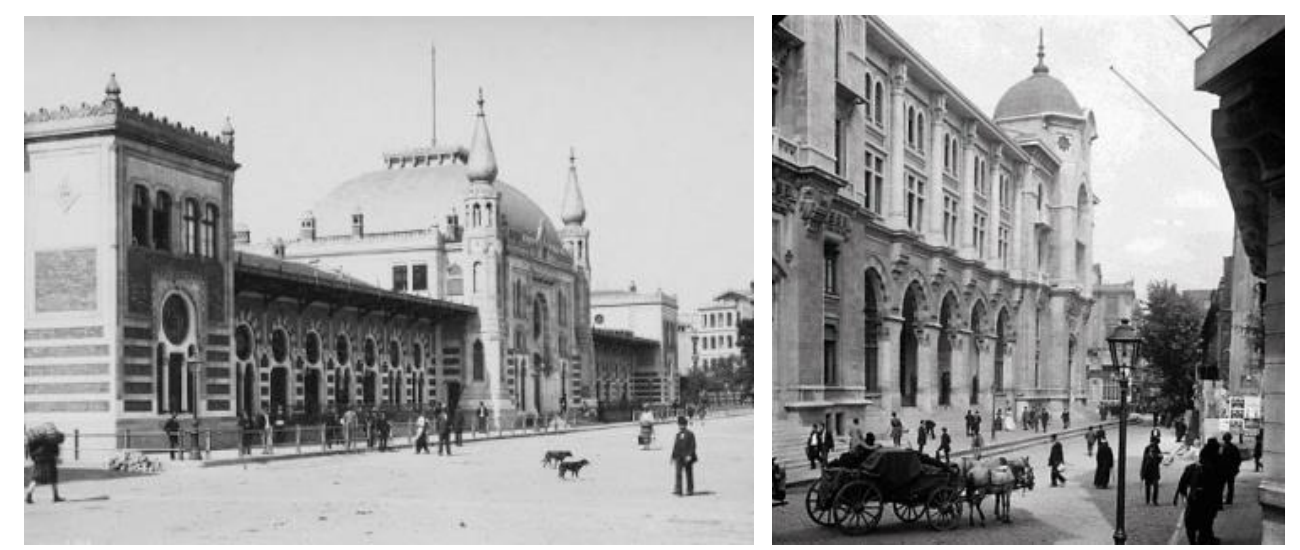

Figure 5. Sirkeci Railway Station-1890 (left) and General Post Office-1909 $(\text { right })^{11}$

\section{The Construction of Galata Bridge}

Galata Bridge, which links the Historical Peninsula and Galata district of Istanbul, has taken an important role in the change of Eminönü Square. Thus, the former urban area that existed on the shore was directed towards Galata. The bridge was re-built many times during different periods. The Galata Bridge of 1875 brought along changes in the building style and construction in the area. With the construction of the new bridge, many masonry buildings of

10. Dogan Kuban, "Eminönü," in Dünden Bugüne İstanbul Ansiklopedisi 158-64 (Istanbul: Kültür Bakanlığı ve Tarih Vakfı Ortak Yayını, 1994).

11. Ibid. 
two, three or four-storey height appeared in the area. These masonry buildings first covered the city walls in front of Yeni Valide Mosque, which were sided by shops in the former periods. ${ }^{12}$ Then, the walls were replaced by new constructions and buildings, which had continued the line of the walls until the 1930s. The impact of the construction of the bridge had been considerable for the development of Eminönü Square in the $19^{\text {th }}$ century.

The bridge provided access between the two important commercial districts of Istanbul, Karaköy and Eminönü. Moreover, the bridge added new density to the square especially with the vehicular traffic. These flows did not immediately change the plan of Eminönü Square through the $19^{\text {th }}$ and the early decades of the $20^{\text {th }}$ century. ${ }^{13}$ In conclusion, it could be argued that the bridge added more traffic and stimulated urban life on the Square. Besides, it changed the construction and style of buildings at the points of bridge heads. Also, the vitality of Eminönü Square could be observed from the photograph. The boats, the officials, and the pedestrians were the main signs of circulation reflecting the mobility and density in the square. Towards the end of the 19th century, this circulation on the bridge brought a lively and crowded life to Eminönü Square in accordance with the image of a central business area in historic Istanbul (see Figure 6).

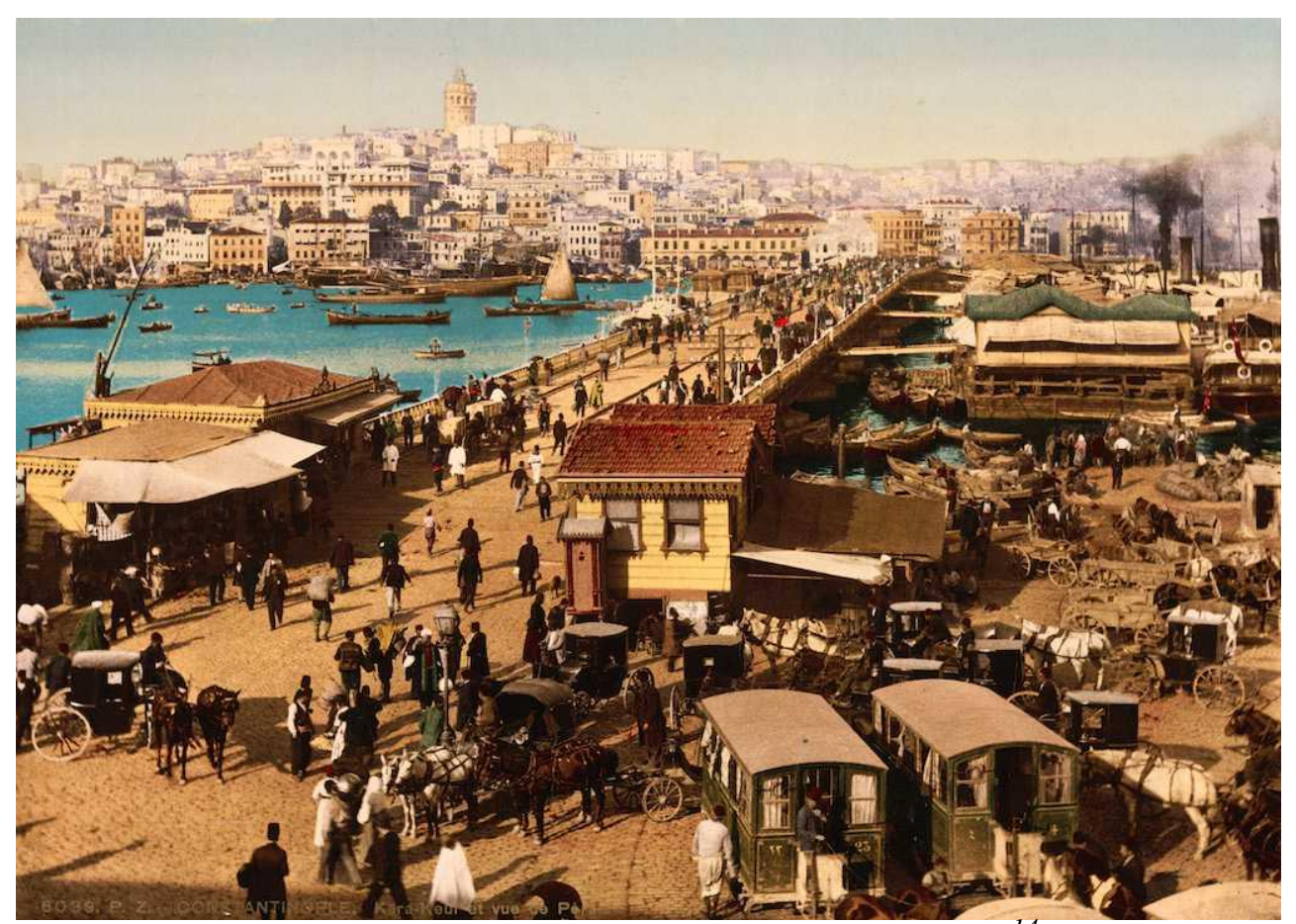

Figure 6. The Eminönü Entrance of the 1876 Galata Bridge $e^{14}$

12. Erkal, Haliç Extra-Mural Zone: A Spatio-Temporal Framework for Understanding the Architecture of the Istanbul City Frontier, 2001.

13. Eremya Celebi Komurciyan, "İstanbul Tarihi: Xviii. Asırda İstanbul," (ed.) Hrand D. Andreasyan (İstanbul: Eren Yayınc1lık, 1988).

14. Burcak Evren, Galata Köprüleri Tarihi (Istanbul: Milliyet Yayınları, 1994). 


\section{Henri Prost's Plan for Istanbul in $20^{\text {th }}$ Century}

Henri Prost, who was invited to Istanbul by Atatürk in the Republican period (1922-1938), was assigned to form the city master plan as one of the leading city planners. While developing the master plan of Istanbul, Prost aimed to protect the city's own topography, texture and architectural monuments, while also equipping it with contemporary infrastructures of the new age. According to Prost, Istanbul is not only a historical city, but also a European city. Prost anticipated a major transformation with the opening of new roads to the historical Istanbul, new equipment and, if necessary, the creation of new districts. ${ }^{15}$

Henri Prost's plan focused on main issues such as the railway and maritime transportation, the commercial center, small-scale industry and its developments, the modern buildings and the road networks in the urban area of Istanbul. The main road network of Istanbul was re-planned by Prost as a significant development. Prost proposed both a main road, which would provide a connection between the north and the south of the city, and proposed a new road at the edge of Haliç and Marmara. The new road network required the opening of new avenues and streets in the urban area (see Figure 7).

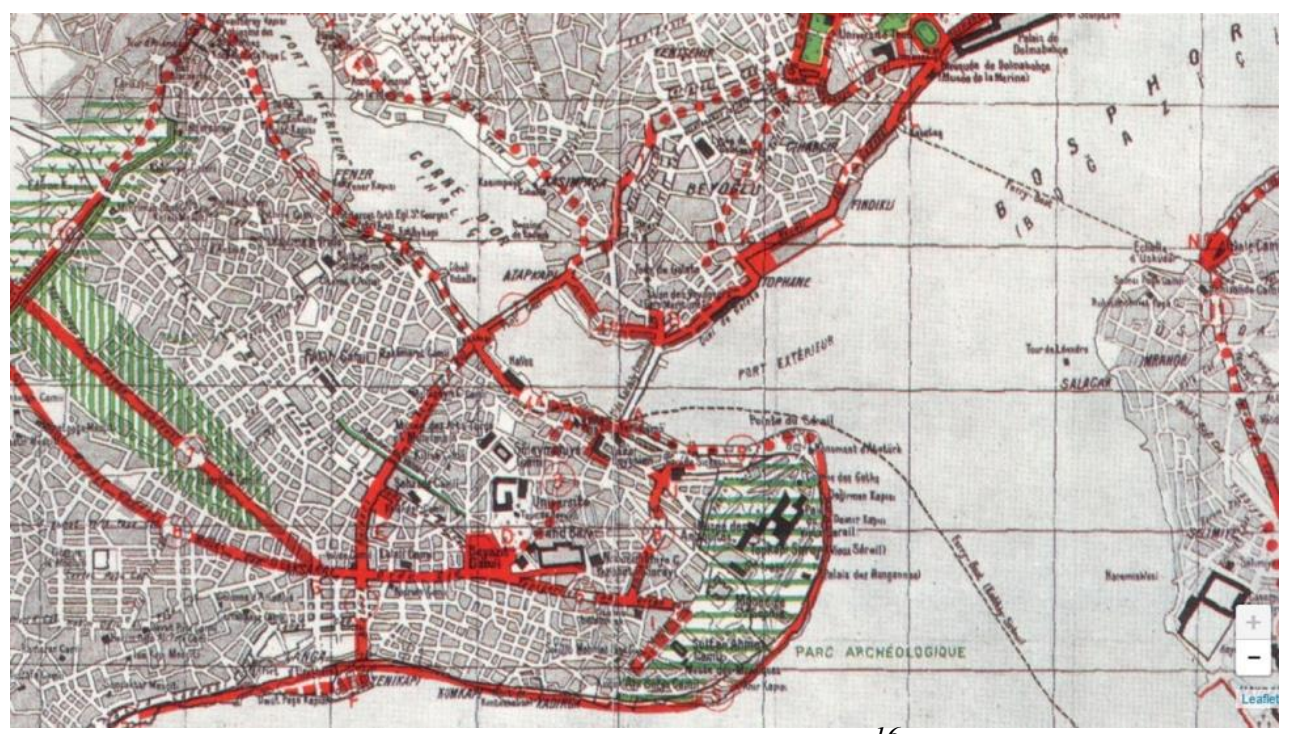

Figure 7. Henry Prost's Road Network for Istanbul ${ }^{16}$

One of the major plans of Prost was related with re-shaping of Eminönü Square. According to planning, it was designed as a new public square in the Eminönü district by the demolition of buildings on the northern side of Yeni Valide Mosque. Creating vistas and perspectives were the main design principles of Prost's plan. With the demolition of buildings and the re-arrangement of the square, the removed buildings or the expropriated areas caused a noticeable

15. Cana Bilsel, "Shaping a Modern City out of an Ancient Capital: Henri Prost's Plan for the Historical Peninsula of Istanbul," in 11th International Planning History SocietyIPHS (Barcelona, 2004).

16. IBB, "Istanbul Urban Layers." 
change in the urban area. These removed buildings defined the southern edges of the square before the operation of Prost. The foreground of Eminönü Square was totally changed by the demolition of the buildings. The structure of the Yeni Valide Mosque, the Sultan kiosk and the Egypt Bazaar came to the forefront. These monumental buildings became the major pieces defining the modern square (Figure 8).
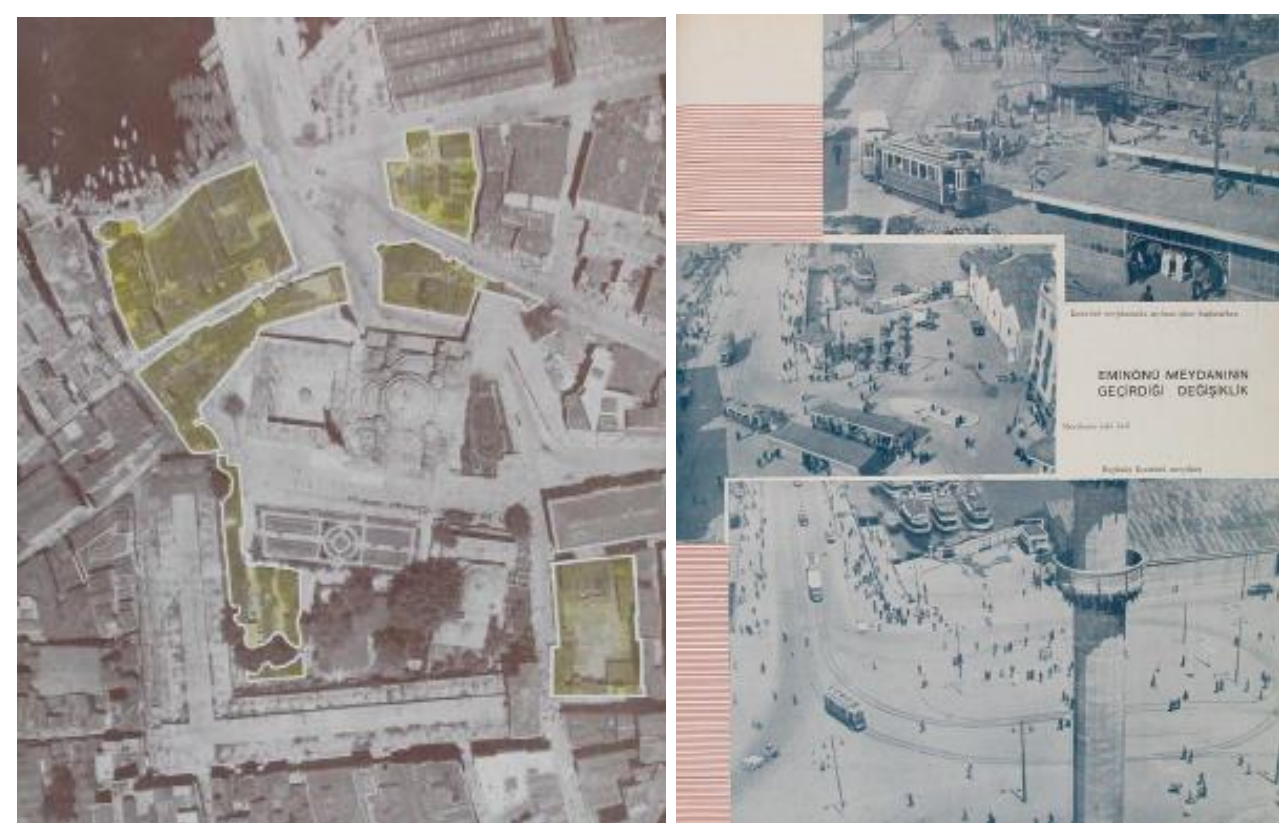

Figure 8. The Expropriation Areas and the Transformations of Eminönü Square in the $1940 s^{17}$

The Yeni Valide Mosque dominated the square as a principal vertical element. A new terrace and staircases were added in front of the mosque to increase its visual effect when coming from the Galata side. The mosque continues to dominate the square as a monumental structure today. Moreover, the Egypt Bazaar was restored in the 1940s and the buildings in front were demolished as well to open the entrance façade of the building. While the demolitions of the buildings broadened the area of Eminönü Square, the central transportation system started to change its position by operations such as the tramway station moving to another place. ${ }^{18}$

The shops between the southern side of the mosque and Egypt Bazaar, where the harim existed in the Ottoman period, were cleaned and a park was planned in their place. The complex relation between the religious and the commercial activities on the southern side of the mosque disappeared. After the planning operations of Prost on Eminönü Square, some photographs show that the arrangement of the modern square with this new park and new roads are considerable alterations in the urban fabric. These operations completely

17. Tumay Cin, Transformation of a Public Space in Istanbul: The Eminönü Square (METU, 2006).

18. Ibid. 
changed the traditional space of Eminönü by adding different functions and structures to the square.
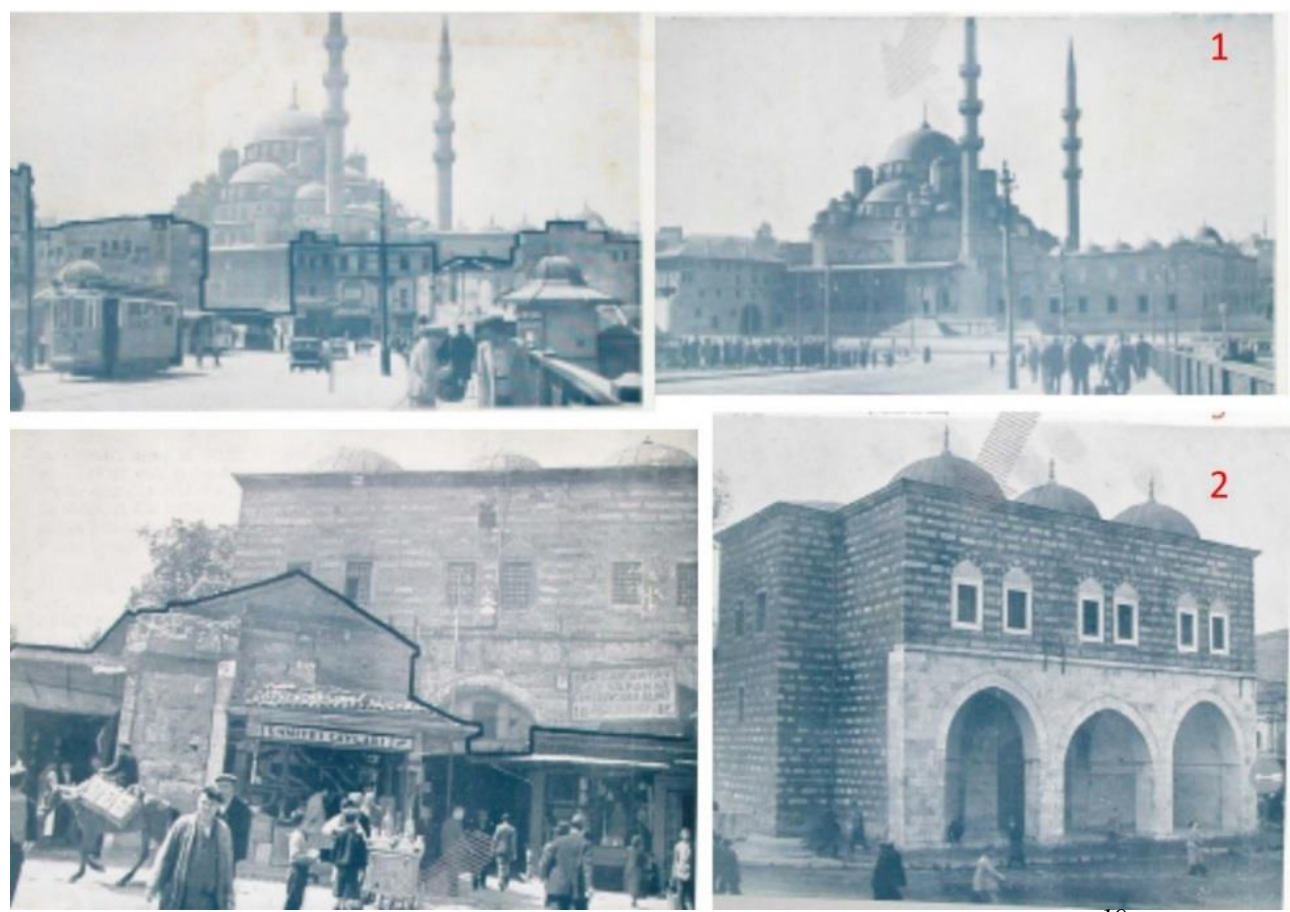

Figure 9. The Pictures Comparing the Foreground of the Square ${ }^{19}$

The front facade of Eminönü square was defined by the two three-storey buildings seen in the first picture. They define the surrounding space and the border of the square (see Figure 9). The only opening, which was the former Yeni Camii Gate, let the eye move out of the square. The horizontal elements of the front were dominated by the vertical monumental structure of the mosque. The second picture also shows the other changes to the forefront of the square. The buildings in front of the Bazaar were demolished as well to open the entrance façade of the building. They provide a relationship between the public and private areas with their opening through the street. There were no shops on the entrance of the Bazaar in the 1940s. The relationships between the inside of the Bazaar and outside could not be seen anymore.

Today, the Yeni Valide Mosque continues to dominate the square as a vertical element that can be easily noticed from Galata, the European part of Istanbul. As one of the monumental pieces defining the area, Egypt Bazaar and its additional structures play a key role in the development of the square in accordance with the mosque. Prost's planning of Eminönü Square develops a new context for both the square and open public spaces in the urban area. ${ }^{20}$ The square resembles a plaza as in European cities. The harim (central prayer hall) of the mosque is opened thoroughly to public use. This change reflects

19. IBB, Güzelleşen İstanbul-Xx. Yüzyıl (Istanbul: İstanbul Maarif Matbaas1, 1943).

20. Cana, "Shaping a Modern City out of an Ancient Capital: Henri Prost's Plan for the Historical Peninsula of Istanbul," 2004. 
the understanding of open public space also represented within the context of 'modernization' ideology of the Republican period.

\section{Discussion: Towards the Current Image of the Eminönü Square}

Considering the recent transformation of Eminönü district in the $20^{\text {th }}$ century, the Prime Minister Adnan Menderes, who took over responsibility for the reconstruction of the city in 1956, realized a rapid urbanization process with intensive road building, street widening, demolition of old buildings and construction of new ones. There was in fact continuity between Prost's plan and the urban operations carried out by Menderes. The general decisions of Prost's plan were followed by the re-construction works of Menderes. The Fish Market (Balıkpazarı) disappeared with the opening of the main road of Eminönü-Unkapanı between 1955 and 1956. The area that was planned in the time of Menderes could be observed from the first picture.
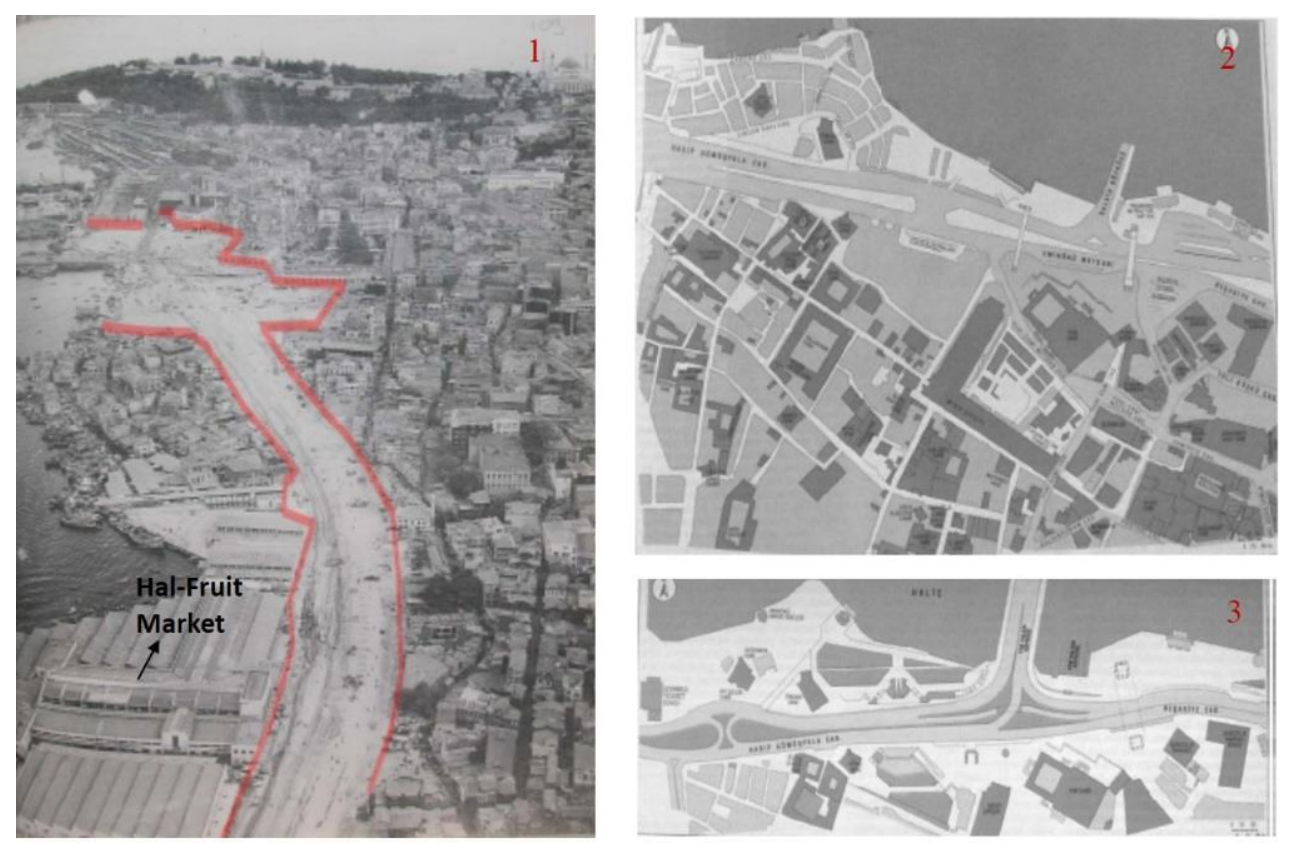

Figure 10. The Urban Interventions related to the Eminönï District in the Period of Menderes and Dalan before the $21^{\text {st }}$ Century

The buildings between Eminönü and Unkapanı were thoroughly demolished, except the Hal-Fruit Market Building, in this period. The welldefined boundaries of Eminönü Square started to lose their local characteristics. The demolitions created large voids on the western side of Galata Bridge ${ }^{21}$. The densely built urban fabric of the square was replaced by these voids. The first picture shows the opening of Eminönü-Unkapanı Road in the period of

21. Cem Behar, “Osmanlı Döneminde İstanbul'a Göçler Ya Da Göç Olmadan İstanbul İstanbul Olabilir Miydi?” (ed.) Murat Güvenç, Eski İstanbullular and Yeni İstanbullular Sempozyumu (Istanbul: Osmanlı Bankası Arşiv ve Araştırma Merkezi, 2009). 
Menderes, whose operations were realized between 1950 and 1960. The second image presents the planning of the Eminönü district in 1985, before the destruction of the Golden Horn and the construction of a new bridge. The third picture displays the plan of the district in 1994, after the destruction of the Golden Horn and the construction of the new bridge (see Figure 10).

Urban operations in the 1980s brought another period of transformation for Istanbul, including Haliç. Under the leadership of the Mayor Bedrettin Dalan, large-scale projects were developed in the context of rapid urbanization processes supported by the liberalization policy of the state. One of the most radical projects of the period was to clear the banks of Haliç from industrial uses. The building stock that formed the industrial heritage was all demolished, and the whole shoreline was transformed into a green recreational area. After the Hal-Fruit Market buildings were demolished in 1987, the land of the market was turned into an open green area. The local urban fabric along the shores of Haliç totally disappeared through these urban interventions ${ }^{22}$. These extraordinary operations caused various critiques and discussions among the city planners, architects, and non-governmental organizations. The challenge of this transformation was based on the continuity between the historical-local and modern images of the city. Modern urban operations resulted in the damage of historical-local patterns of the city due to the unlimited and unplanned urbanization process of Istanbul.

Considering the transformation of Eminönü Square at the present, several urban design projects are developed for the rearrangement of the Square with new dynamics and functions for the $21^{\text {st }}$ century. However, they have not been realized due to the lack of comprehensive planning of Eminönü district. Many of these projects try to provide uninterrupted pedestrian circulation in the area. Although most of the projects suggest keeping the vehicular traffic underground, the bus stops and the metro stops on the ground provide 'publicness' by creating activity points in the area. These projects do not propose any arrangement for new activities to keep vitality in the square. In this context, it can be argued that the urban design projects proposed for the improvement of Eminönü Square cannot achieve continuity of public life on the square and its surroundings.

In brief, the projects developed for Eminonu Square have generally been based on the physical standards of the place, and therefore practices have not gone far beyond the layout of the floor and urban furniture. The area has been transformed into intersections serving vehicles, or it has been torn apart by large roads passing through it and has thus lost its local function. Eminönü Square also has been affected by this process, and after the extended vehicle routes, it was divided into challenging roads and transformed into an open area with a disconnected relationship with the sea. Today, Eminönü Square is a hub where different user profiles prefer it for transit to access various functions in the Historical Peninsula of Istanbul (see Figure 11).

22. Hatice Ayatac, "Influence of International Planning Ideas on Istanbul's Urban Fabric," paper presented at the 14th IPHS Conference, 2010. 


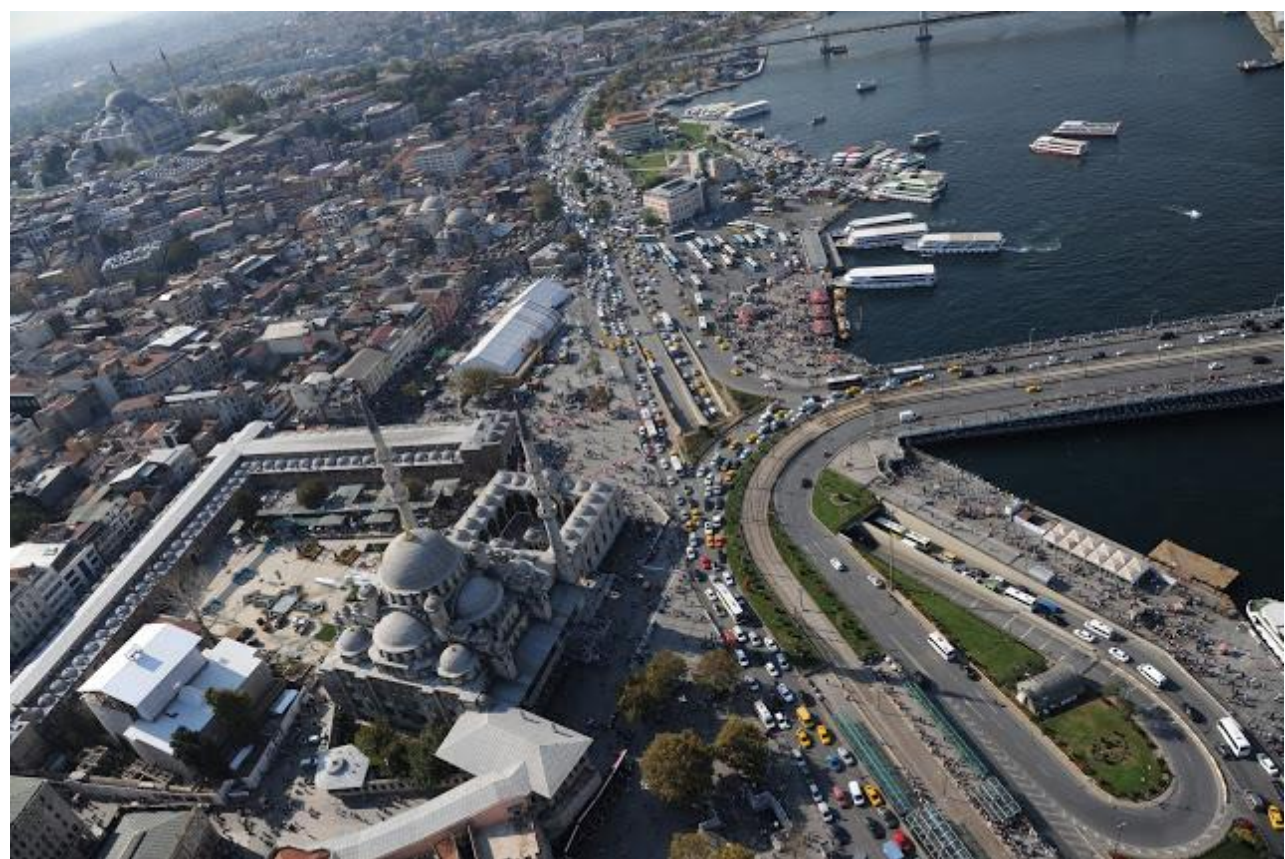

Figure 11. Eminönü Square with Galata Bridge, Yeni Valide Mosque and Egypt Bazaar and the Main Traffic Arteries surrounding the Area, 2017

With becoming a transportation hub connecting the main arteries surrounding Eminonï, the square is transformed into a space which is mainly used for the transit of urban people. On the other hand, the main road network through the southern end of Eminönü Square interrupts both the accessibility of the pedestrians and the connection with the sea. Within the context of landscape studies in the area, the hard pavement materials with grey color stones are used to separate the pedestrian traffic from the vehicular traffic. This part of Eminönü Square, which lacks landscape elements, is used as a passageway (see Figure 12).

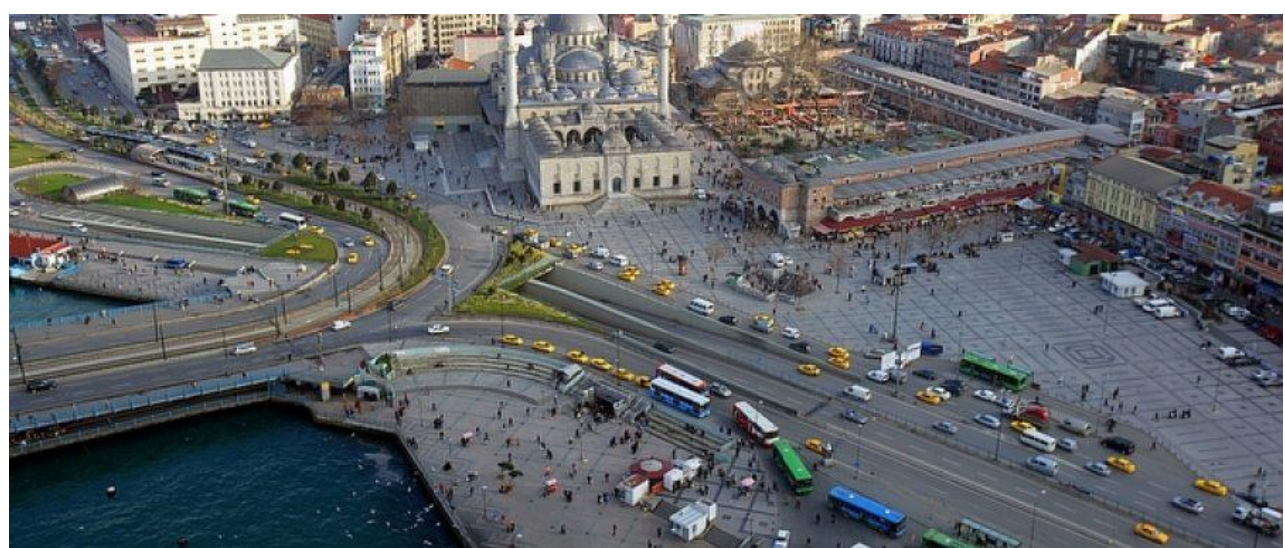

Figure 12. The Image of South-western Sides of the Eminönü Square, Reflecting the Pedestrian and Vehicular Circulation in the Area

The square comes to the forefront as a transition space at the center of transportation systems and activities. However, the current image of Eminönü 
Square reflects various functions, such as commercial, touristic and some traditional uses, like fishing on the Galata Bridge, besides transportation. The function of being a trade center from the past to today has not changed, and Eminönü Square continues as a place of small industry and trade with its local markets, khans and shopping units visited by both local users and tourists.

\section{Conclusions}

As the former business and trade center of Istanbul, Eminonü reflects many different urban patterns related to its various functions and spaces. Being the center of urban transportation and functions from the past to the present, the physical space of the district, as well as its formation, reflects a highly heterogeneous structure. Eminonü represents how Istanbul has always been a center for trade, production and traditional markets throughout history. It continues the function of being a trade center with some of local markets and shopping units surrounding the square. In addition to that, Eminönü has become one of the rarest areas in Istanbul that continues some traditional uses despite the new functions and structures developed in the area. Therefore, this research aims to reveal the changing urban pattern of Eminönü depending on reconstruction processes of the square in different periods, considering the functional intensity and circulation mobility in the area. The case study consists of Eminönü Square and its connected structures such as the harbor, commercial areas, passing areas and other functions.

Eminönü Square is one of the strategic locations in Istanbul with a variety of functions and spaces. Yeni Valide Mosque, the Galata Bridge, the Fish Market, and the Egypt Bazaar are the structural landmarks of Eminönü Square. Also, the square comes to the forefront as a transition space at the center of transportation systems and activities. However, despite decreases in the spatial quality of the urban public space, Eminönü Square is still used by a variety of people for different purposes. This mobility of circulation depends on its strategic location between two important parts of the city: Galata and the traditional central business district of the Historical Peninsula. The square has always been a transition point between these two important districts of the city. In other terms, Eminönü Square behaves as a gate to the historical city of Istanbul. Although this relation has not changed, the density of uses and structures surrounding the square has changed through time. Today, Eminönü Square transforms into a space where different user profiles, functions and spaces create a heterogenous structure, in the context of modernization of the Historical Peninsula of Istanbul.

The radical changes Istanbul faced between the $19^{\text {th }}$ and $20^{\text {th }}$ centuries have caused a transformation of the local context of Eminönü Square. The urban interventions that affected the form and the structure of the square coincide with the urban planning process. By the planning of the new road network and the demolishing of some structures defining the square, the welldefined boundaries of Eminönü Square started to lose its characteristics. All 
these operations have affected the current image of Eminönü Square creating undefined open areas in the urban pattern. From the $19^{\text {th }}$ century to the $21^{\text {st }}$ century, the urban voids, creating undefined open areas in the urban pattern, have become more dominant than urban solids enclosing and defining the Eminönü district. Depending on the demolition of buildings with Menderes and Dalan's operations on Eminönü district, the gradually disappearing solidvoid relation on the square was affected by the sense of enclosure.

In conclusion, the current image of Eminönü district shows a palimpsest character, and the place is transforming with new periods, structures and functions. Accordingly, the boundaries of the district are changing, while creating a new urban fabric in Istanbul. The differences between the periods caused a variety of planning and urban interventions on Eminönü Square. The sense of enclosure on the square has weakened with the demolition of the buildings. In this context, it is observed that Eminönü Square lost its welldefined formal structure, which caused corruption in the activities' qualities and the legible identity of the square. The opening of large voids in the area affected the quality of the square negatively both in formal, visual and perceptual aspects.

\section{Bibliography}

Ayatac, Hatice. "Influence of International Planning Ideas on Istanbul's Urban Fabric." Paper presented at the 14th IPHS Conference, 2010.

Behar, Cem. "Osmanlı Döneminde İstanbul'a Göçler Ya Da Göç Olmadan İstanbul İstanbul Olabilir Miydi?" [Migrations to Istanbul in the Ottoman Period Or Istanbul Without Migration Could it be Istanbul?] Edited by Murat Güvenç, Eski İstanbullular and Yeni İstanbullular Sempozyumu. Istanbul: Osmanlı Bankası Arşiv ve Araştırma Merkezi, 2009.

Bilsel, Cana. "Shaping a Modern City out of an Ancient Capital: Henri Prost's Plan for the Historical Peninsula of Istanbul." In 11th International Planning History Society-IPHS. Barcelona, 2004.

Celik, Zeynep. 19. Yüzyılda Osmanlı Başkenti: Değişen Istanbul19.Yüzyılda Osmanlı Başkenti: Değişen Istanbul [Ottoman Capital in 19th Century: Changing Istanbul 19th Century Ottoman Capital: Changing Istanbul.] Translated by Selim Deringil. Istanbul: İş Bankası Kültür Yayınları, 2016.

Cin, Tumay. Transformation of a Public Space in Istanbul: The Eminönü Square. METU, 2006.

Erden, Dilek. "Haliç’te Dönüşüm Ve Tarihsel Süreklilik" [Transformation in the Golden Horn and Historical Continuity.] In Osmanlı Bankası Arşiv ve Araştırma Merkezi, 2009.

Erkal, Nuran. Haliç Extra-Mural Zone: A Spatio-Temporal Framework for Understanding the Architecture of the Istanbul City Frontier. METU, 2001.

Evren, Burcak. Galata Köprüleri Tarihi [Galata Bridge History.] Istanbul: Milliyet Yayınları, 1994.

IBB. "Güzelleşen İstanbul-Xx. Yüzy1l" [Beautiful Istanbul-Xx. Century.] Istanbul: İstanbul Maarif Matbaas1, 1943.

. "Istanbul Urban Layers." http://www.istanbulurbandatabase.com/. 
Vol. 4, No. $1 \quad$ Sari: Changing Urban Pattern of Eminönü: Reproduction of...

Isin, Ekrem. İstanbul'da Gündelik Hayat [Everyday Life in Istanbul.] Istanbul: İletişim Yayınlar1, 1995.

Komurciyan, Eremya Celebi. Istanbul Tarihi: Xviii. Asirda Istanbul [History of Istanbul: Xviii. Istanbul for centuries.] Edited by Hrand D. Andreasyan. Istanbul: Eren Yayınc1lik, 1988.

Kuban, Dogan. "Eminönü." In Dünden Bugüne İstanbul Ansiklopedisi 158-64. Istanbul: Kültür Bakanlığı ve Tarih Vakfı Ortak Yayını, 1994.

__. Istanbul an Urban History. Istanbul: Economic and Social History Foundation of Turkey, 1996.

Ortayli, Ilber. İstanbul'dan Sayfalar [Pages from Istanbul.] Istanbul: İletişim Yayınları, 2000.

Ulgen, Ali Saim. "Yenicami." Vakıflar Dergisi 2 (1974): 75-78. 